December 30, 2004

BOFIT Discussion Paper

Presented to Conference on

"Systemic Financial Crises: Resolving Large Bank Insolvencies"

Federal Reserve Bank of Chicago, September 30, 2004

\title{
Dealing with Financial Fragility in Transition Economies*
}

\author{
John Bonin \\ Wesleyan University \\ and \\ Paul Wachtel \\ New York University, Stern School of Business
}

\begin{abstract}
We examine the efforts of transition economies to deal with financial fragility and resolve banking cries We characterize the birthing process of banking in transition and the three essential features of banking crises in transition economies: (i) bad loans and the relationship to state owned industries, (ii) development of institutional infrastructure and (iii) credible commitments to resolution and privatization. We then discuss the experiences of seven important transition countries in order to identify the salient features of their efforts to resolve banking crises.

JEL Classifications: G21, P34

* The authors are grateful to Diana Kniazeva, Radosalava Petrova, and Elif Sisli for research assistance and thank Rainer Haselmann, Pavel Kapinos and Diana Kniazeva for helpful comments.
\end{abstract}

Corresponding author: Paul Wachtel, Stern School, New York University, 44 West $4^{\text {th }}$ Street, New York, NY 10012, 212-998-4030; pwachtel@stern.nyu.edu 
The resolution of bank crises in the transition economies, at least until the late 1990s, differs from resolution elsewhere. Transition banking experienced a birthing stage in which a decentralized private banking system was carved out of the vestiges of a public monobank structure. The banks carved out of the state monobank were often undercapitalized and, most importantly, were expected to support the state-owned enterprises (SOEs) in the evolving market economy. Furthermore, the state-owned commercial banks (SOCBs) were often joined by poorly capitalized and loosely regulated new entrants. In essence, the birthing process provided the seeds of banking crisis. However, calling transition banking a special case begs the issue of understanding how these countries corrected the situation relatively quickly. Although the transition experiences in dealing with financial fragility were often costly and sometimes drawn out by a slow learning process, most countries in the region now have remarkably strong banking systems.

In this paper, we examine the experiences of transition economies with financial fragility. In the first section, we characterize the birthing process and the three essential features of banking crises in transition economies. In the next section, we examine the experiences of seven important transition countries in order to identify the salient features of their efforts to resolve banking crises. Our reflections on these experiences are found in a concluding section.

\section{Banking in transition countries: the birthing process}

Banking sectors in transition economies (TEs) underwent a birthing stage in which a decentralized private banking system was carved out of the vestiges of a public monobank structure. In some TEs, a single new bank assumed the entire commercial portfolio of the monobank; in others, several new commercial banks were born. In addition, one or more large specialty banks existed having monopolies over their respective core activities, e.g., a savings bank for primary deposits and a foreign trade bank for all foreign currency transactions. The resulting state-owned commercial banks (SOCBs) were undercapitalized and expected to support the state-owned enterprises (SOEs) in the evolving market economy. In addition, entry requirements were relatively lax to induce domestic competition so that poorly capitalized and loosely regulated private entrants added to the seeds of banking crises.

Governments in the TEs faced three interrelated major tasks in developing efficient banking sectors from this embryo. First, most of the SOCBs were insolvent. Prior to transition, loans were not made according to market criteria so that many of the existing assets held by these banks became non-performing in the market economy. In addition, the situation was exacerbated at the outset of transition by governments that were eager to eliminate fiscal deficits. They eliminated fiscal subsidies to SOEs, which turned to their SOCBs for financial support. Therefore, the first task for developing independent banking sectors was to correct the incentives that generated bad lending and to make transparent the financing of government policies. 
Bank insolvency has two components, namely the stock of inherited bad loans and the flow of new bad loans. To prevent the recurrence of insolvency, any resolution program must remove from the banks both the incentives to make bad loans and the impediments that prevent them from extricating themselves from weak clients. To the extent that SOCBs are unable to shed SOEs that cannot perform profitably in the market environment, providing financial support for these clients insures that bad loans will continue to impact adversely the solvency of SOCBs.

The second task, creating the institutional and legislative infrastructure to support and facilitate the transition to a market economy, was of equal importance. Without the supporting institutional and legislative infrastructure, neither the information nor the incentives for resolving bank insolvencies are forthcoming. Therefore, institution building is necessary although it is not sufficient. Specifically, bankruptcy laws and accounting standards were required to change the behavior of economic agents who were accustomed to operating in the non-market environment and human capital development was needed to for effective implementation. Proper attention must be given to the incentives of individual decision makers if the legislation is to be implemented successfully. Hence, any resolution program must be integrated carefully with the evolving institutional structure to avoid inconsistencies and unwarranted expectations. Since the SOCBs held the predominant share of banking assets, the third task was bank privatization.

To avoid a moral hazard problem, the government must be able to commit credibly to a final resolution of the insolvency problem. Multiple recapitalizations of SOCBs in the TEs were taken as evidence of an inability or unwillingness on the part of governments to harden budget constraints on banks and, by association, their client SOEs. In retrospect, a combination of the difficulties of recognizing the full extent of the problem due to the dynamics and a reluctance to allow banks to sever relationships with existing weak clients influenced significantly the policy options.

The EBRD identifies 27 TEs (not counting China and the other Asian TEs) although the group is probably no more alike than any random sampling of nations around the world. Included are large countries, e.g. Russia, and extremely small countries, e.g. Slovenia and Estonia. Considerable differences in the level of development are observed from Central Europe to Central Asia leading to significant differences in banking systems. In order to provide an overview of the salient issues, we focus on seven TEs that have different characteristics and progress in bank restructuring. We include the two largest TEs, namely, Russia and China, and we consider the TEs with the most developed banking systems, both at the start of transition and at the present, namely, Poland, Hungary and the Czech Republic. In addition, we consider two other TEs with a long history of grappling with banking development, namely, Bulgaria and Romania. Our choices do not include very small countries, those with idiosyncratic political situations (e.g. former Yugoslavia) or those with minimal extent of financial intermediation (e.g. some CIS republics). 
A stable macroeconomic environment is a necessary condition for effective financial intermediation. Macroeconomic stabilization occurs when the transition shock to output comes to an end and the inflation rate stabilizes below hyperinflation levels. Appendix Tables 1 and 2 show annual real GDP growth rates and inflation rates respectively for the seven countries in the seven countries discussed. Using positive real growth and an inflation rate of $50 \%$ as thresholds, we date macroeconomic stabilization as follows: Poland, 1992; Czech Republic, 1993; Hungary, 1994; Russia, 1997; ${ }^{1}$ Bulgaria, 1998; and Romania, 2000. The birthing process for the banking system continued beyond the point of stabilization in the earliest stabilizers, i.e., Poland and, particularly, the Czech Republic. In the other countries, bank restructuring corresponded fairly closely with the date of macroeconomic stabilization. We will see in country discussions that there is a joint causality between bank restructuring and macroeconomic stabilization. Each makes the other possible. An interesting exception is China that experiences neither negative growth nor high inflation throughout the period and, interestingly, has just begun to restructure its banks.

The impact of a banking crisis or of a slow birthing process depends on the depth of financial intermediation in these countries. A banking crisis has less impact on an economy based on cash transactions than on one with extensive use of bank deposits. ${ }^{2}$ As long as the government has a mechanism in place for the distribution of currency, bank insolvencies have no systemic effect. ${ }^{3}$ Appendix Tables 3 and 4 provides annual data for two measures of financial depth, the ratio of M2 to GDP and the ratio of domestic credit to provided by the banking sector to GDP. Hyperinflation at the start of transition often reduced the extent of intermediation, particularly in Bulgaria and Romania. Although these countries, and Russia as well, had very costly banking crises, they were able to start a macroeconomic recovery quickly. The Czech Republic and Hungary had deeper financial systems in the 1990s and therefore larger macroeconomic consequences of banking crises. Finally, China has a comparatively deep financial system and therefore may be vulnerable to the effects of any banking crisis that might occur. Since banking crises and macroeconomic contractions are occur simultaneously, we do not provide specific estimates of the macro consequences of each crisis. However, efforts to restructure the banking system can be estimated.

For estimates of the costs of bank restructuring programs, we draw on those found in Caprio and Klingbiel (2003), Tang et al. (2000) and Zoli (2001). Bonin and Wachtel (2003) summarize banking developments in transition and Enoch et al. (2002) addresses the issue of resolution.

\section{Resolving bank crises in transition countries}

Poland. A two-tier structure was established in 1989 resulting in a central bank, nine regionally based SOCBs and four specialty banks. In 1991, the Polish government recapitalized banks to cover losses from the currency devaluation. By 1993, nonperforming loans were still 31\% of total bank loans as banks continued to lend to their non-restructured SOE clients. With the support of the World Bank, the Polish government designed a bank-led, enterprise restructuring plan that linked bank 
privatization and recapitalization with bad-debt workouts. In addition, the agricultural bank BGZ, which is an umbrella for numerous agricultural cooperative banks, was recapitalized. The government also made efforts to restructure the industry by orchestrating mergers through a bank consolidation program. Caprio and Klingbiel (2003) indicate that the cost of recapitalizing the seven commercial banks in 1993 was $\$ 750$ million and the cost of recapitalizing the agricultural banks was $\$ 900$ million. Zoli (2001) estimates the total fiscal cost of all restructuring efforts in Poland at only $7.4 \%$ of GDP, most of which was due to initial recapitalizations in $1991 .{ }^{4}$

Throughout this period, the payments system functioned with a few notable early problems due to the underdeveloped infrastructure for clearing checks among the regional banks. In addition, financial depth did not decline and foreign participation, both greenfield and in the privatization process, began after 1995. The legal infrastructure, which was largely the pre-Communist commercial code because extensive legal reforms did not occur until the later 1990s, was adequate for the early development of the banking sector. The central bank operated at arms length from bank restructuring and played an effective supervisory role. By 1998, a majority of the banking system was private and, by the end of the following year, more than half of bank equity was foreign owned.

The fundamental characteristic of the Polish approach to bank restructuring is that the responsibility for working out bad loans was retained by the banks, which were expected to promote enterprise restructuring. The program was intended to build institutional capability in the banks and provide flexible enterprise restructuring without government interference. The underlying presumptions were that the major bank creditor had sufficient information about their large SOE clients either to promote restructuring or to opt for liquidation and that the banks had sufficient incentives to maximize debt collections. Actual experiences indicate that restructuring dominated bankruptcy and that the main workout instrument used by the weaker banks was the debt-equity swap. Bonin and Leven (2001) find that new credit extended to three large military-industrial clients by one SOCB in the program exceeded the total amount of the bank's recapitalization and left it with more, rather than less, exposure to these clients. Hence, Poland's program strengthened, rather than severed the ties between banks and their undesirable clients and provided breathing room for weak SOEs to postpone painful restructuring.

Hungary. The birthing process in Hungary started with the establishment of the SOCBs in 1987 and a regulatory agency in 1992. Although the initial steps were appropriate, two sources of difficulty emerged. First, lax entry standards resulted in the creation of many small and poorly capitalized or poorly run de novo banks that were responsible for several instances of fraud. Many of the de novo banks became insolvent and were either closed or forced to merge with other institutions. Although this experience threatened the stability of the financial system, no systemic crisis or explicit bailouts by the government or the central bank occurred. Second, the establishment of the SOCBs did little to change the relationship between banks and their traditional SOE customers, particularly because the banks were organized along sectoral lines. Bad loans by SOCBs to SOEs accumulated rapidly. Moreover, improvements in accounting rules 
for classifying loans and new bankruptcy legislation served to indicate that the bad loan problem was large and growing. ${ }^{5}$

In an initial effort to recapitalize banks in 1991, the Hungarian government extended loan guarantees for inherited bad loans. The government bought loans and interest claims that totaled almost 3\% of GDP and paid for them with specially issued bonds. About one-third of the loans were transferred to a factoring agency for workout and the rest was left with the banks to work out under contracts with the Ministry of Finance that restricted new lending.

The Hungarian approach involved dealing with bank recapitalization, enterprise restructuring, and institutional development simultaneously. During 1993, the government developed a program for the recapitalization of large (non-bank) SOEs. The government bought or forgave debts of these enterprises and the banks received government bonds in excess of 1\% of GDP as part of the program. Nevertheless, the amount of bad or doubtful debt at the banks kept increasing and another comprehensive recapitalization followed at the end of 1993 when capital injections of more than \$1 billion were made. The recipients included the three large SOCBs, which accounted for over half of the overdue credit in the banking system and were insolvent. Later stages of the program in 1994 provided additional financing and incentives to deal with bad loan problems. The total amount provided was somewhat less than 2\% of GDP and the three large commercial banks received over $80 \%$ of the funds involved.

Multiple recapitalizations of its SOCBs earned Hungary the dubious reputation at the time as being the country most oblivious to moral hazard. The first recapitalization was insufficient both because the instruments used were not sufficiently liquid or financially attractive and because the banks were still servicing bad clients. The second bank recapitalization was ultimately successful because soon afterwards Hungary adopted a policy of privatizing state banks by selling controlling shares to strategic foreign investors. The willingness of the Hungarian government to sell large banks to strategic foreign owners provided the credible commitment of no further bank bailouts and hastened reforms in the relationships between banks and SOEs. Between mid-1994 and 1997, all of the Hungarian state owned banks were sold to foreign investors.

The Hungarian experience points to the importance of SOCBs achieving independence both from the state and from undesirable clients. By the end of the 1990s, the Hungarian banking sector was the strongest in the region. The costs of the recapitalization programs in the 1990s amounted to 13\% of 1998 GDP (Tang, et. al.).

Although the Hungarian banking sector is largely well capitalized and controlled by foreigners, it has not been immune to banking crises. A few small banks have been liquidated without any direct cost to the government because the deposit insurance agency covered the deposits. In 1997, a run on the sixth largest bank resulted in its nationalization and the subsequent dismissal of the bank's management for fraudulent behavior. It continued to accumulated losses and cost the government 1.7\% of GDP (not included in the above total costs). The bank was privatized in 2003 for about 2.75 times 
its book value illustrating the resiliency of the mature Hungarian banking system to resolve successfully a banking crisis and avoid systemic problems.

Czech Republic. Working capital of SOEs in Czechoslovakia was funded by short-term, low-interest, revolving bank credit (TOZ loans). All of these loans were transferred to a hospital bank and the large SOCBs were freed of bad loans accumulated before 1991. This restructuring program cost about $\$ 750$ million or less than $1 \%$ of GDP. About one third of the funds went to capital infusions to the large banks and the rest was related to the takeover of bad loans. However, the SOE clients remained with their parent banks that continued to provide banking services and new loans. To encourage competition, privatization, and expansion, all banks were given refinancing credits by the central bank.

Three of the largest four banks in the Czech Republic participated in the first wave of voucher privatization in 1992. Investment funds, the largest of which were created by these banks, were an integral part of the Czech voucher privatization program. Hence, this initial divestiture of state holdings in banks and companies resulted in an interlocking ownership of banks and clients in which the state retained large controlling stakes of the privatized banks. The banks maintained their long-standing soft-lending relationships with their voucher-privatized enterprise clients and through the bank-owned privatization funds now held an equity interest in these firms. Voucher privatization strengthened the relationships between banks and their clients and contributed to rapid deterioration of the banks' balance sheets. In addition, the existence of the state-owned hospital bank made it impossible for the government to commit credibly to end further bank bailouts. Moreover, tax laws that restricted write offs and laws that restricted the ability of banks to sell collateral contributed to the growth of bad loans. Although the situation was quickly apparent, several years passed before any meaningful efforts were made to resolve the problems.

In the interim, many small and medium-sized banks encountered liquidity problems, which led to additional resolution programs (Matousek and Taci, 2002). At the end of 1995, a second consolidation program involved closures, liquidations, and mergers of many small and medium-sized banks with the central bank acting as lender of last resort to keep open some of the banks in receivership. Although the 18 banks in this program represented only $9 \%$ of bank assets, fear that a systemic bank crisis provided the rationale for the government's policy. The program cost to the central bank was $2 \%$ of 1996 GDP.

In the summer of 1996, a run on Agrobanka, the fifth largest bank at the time, resulted in liquidity support of over $\$ 500$ million. The government provided liquidity by buying bad assets at face value if the bank agreed to improvements in management, developed a workout plan, reduced risky activity such as securities trading, and obtained infusions of capital from the owners. An additional \$500 million was committed to the program. 
Finally, during 1996 and 1997, a stabilization program covering bad loans in the large banks was enacted to deal with solvency issues. As a consequence of the recapitalization programs, the government once again became the majority owner of the four large Czech banks. Neither the creation of a separate hospital bank for bad loans nor several rounds of cleaning up the banks' balance sheets had made the big four Czech banks strong financial institutions. In 1997, the government belatedly adopted a strategy of selling the banks by auction to foreign strategic investors. The first such sale was the purchase in 199 of Investicni a Postovni Banka (IPB) by Nomura. Nomura took no active role in reforming the bank choosing instead to tunnel value from the bank's investment funds. Large loan losses led to a run on deposits and IPB was taken over by the central bank. The central bank provided a guarantee against future loan losses and removed a further $\$ 2.5$ billion of bad loans from IPB.

Extensive banking system problems persisted throughout the 1990s in the Czech Republic, well after other Hungary and Poland had established mature banking systems. In 1999, 30.6\% of all bank loans were non-performing (Caprio and Klingbiel, 1999). The privatizations of the three large Czech banks were preceded by loan transfers to the hospital bank, which totaled more than 3\% of GDP. Privatization revenues provided some partial offset and in one case, the government provided guarantees against future losses from inherited loans as part of the privatization deal.

Tang et. al. (2000) calculates the present value of restructuring costs in 1998 as $4.8 \%$ of 1998 GDP for the central bank, mainly from the second consolidation program in 1997, and $20.6 \%$ of 1998 GDP for the government, mainly from the initial capital infusion in 1991 and the purchase of bad loans in the early 1990s. However, the hospital bank, which is the principal asset management company in the Czech Republic, has a poor record of collecting debts, has borrowed from the central bank, and has government guarantees. Any further losses incurred by the hospital bank could increase the costs of bank resolution in the Czech Republic, which is already far greater than the costs incurred in Hungary or Poland.

Bulgaria. At the start of transition there were a large number of state-owned banks in Bulgaria, both sectoral banks and regional commercial banks. Following a voluntary merger of 22 of the former credit branches of the central bank to form United Bulgarian Bank (UBB), government-orchestrated restructuring began with the formation of the Bank Consolidation Company in 1993 (Bonin, 2004). However, two impediments to banking sector developed persisted. First, enterprise reform lagged and support for SOEs shifted from the budget to quasi-fiscal subsidies through the banking system. Second, banks routinely granted forex credits to enterprises without holding forex deposits and currency mismatch proved to be a serious problem for the solvency of the banking system. In 1992, the government attempted to address the currency issue by providing banks with government bonds denominated in dollars (ZUNKs) in return for loans. However, responsibility for loan recovery remained with the banks.

The initial efforts at bank restructuring in Bulgaria were an expensive failure. In 1993 and 1994, the costs were $10.9 \%$ and $23.1 \%$ of GDP, respectively. ${ }^{6}$ Two of the 
sectoral banks and UBB required injections of liquidity from the central bank in 1995 and most of the SOCBs were insolvent. About half of all loans in SOCBs were nonperforming but the political will and the legal framework to close down banks was lacking. Finally, in 1996, 19 banks accounting for almost one-third of banking assets were closed. In February 1997, a currency crisis erupted as the lev depreciated significantly. A currency board, established in July 1997 to deal with the macroeconomic crisis, prohibited central bank lending and provided the credible commitment to no further bank bailouts. From 1996 to 1997, bank restructuring costs were shared by the government, through additional loan for bond swaps, and the central bank, through losses on unsecured credits. Total costs amounted to 9.9\% and 4.1\% of GDP in 1996 and 1997, respectively.

Over the decade, the total cost of bank restructuring in Bulgaria was $41.6 \%$ of GDP, far larger than the cost for any other TE. ${ }^{7}$ Bank restructuring failed in Bulgaria for two primary reasons. First, the incentive structure for banks was not changed because bond swaps for bad loans did not stem new lending to the same unreformed SOE clients. Second, the institutional framework for improving the banking system did not exist. Prudential regulations and supervision were not in place until 1997, several years later than in the other ETEs, and international accounting standards were not applied until 1998 (Tang, et al., 2000). Neither the necessary institutional structure nor a credible commitment to abstain from further bailouts existed before the establishment of the currency board.

Romania. The birthing process in Romania resulted in one large commercial bank carved from the portfolio of the central bank, which joined four specialty banks. The balance sheets of these state owned banks were deteriorating from the start. Efforts at macroeconomic stabilization worsened the conditions of some of the banks. Exchange rate liberalization and the elimination of subsidized agricultural credits led to financial distress at the foreign trade bank, Bancorex, and Banca Agricola due to accumulating bad debts from directed credits to the energy and agricultural sectors, respectively. The two banks raised interest rates in 1997 in order to attract deposits and stave off runs, which affected the ability of the central bank to conduct monetary policy. Late in 1997, the government bailed out the two banks with $\$ 1$ billion in bonds, almost 3\% of GDP that were then refinanced by the central bank. At the end of 1998, over $50 \%$ of all bank credit was rated in the loss category and even more in Bancorex. Clearly, the solvency of the entire Romanian banking system was at stake.

The anticipated restructuring of the large foreign trade bank, Bancorex, never took place although a new management team was put in place. The IMF estimates that subsequent mismanagement and delay in restructuring the Bancorex doubled the cost to the public of resolving the crisis. In February 1999, the government established a hospital bank to take over the bad debts from Bancorex and Banca Agricola. Most of Bancorex's loan portfolio was transferred to the agency for workout; initially this amounted to about $\$ 1.7$ billion or 5\% of GDP. However, the bank's problems were insurmountable and Bancorex collapsed in April 1999 after a run by depositors even while efforts to restructure it were ongoing. Since further recapitalization would require a fiscal outlay in 
excess of 5\% of GDP, the government decided to close Bancorex and merge the healthy part of its portfolio with the large state-owned commercial bank. In addition, about \$2 billion more in bad loans from Bancorex and Banka Agricola were transferred to the hospital bank. To avoid a systemic crisis, the central bank provided liquidity. In addition, the government compensated the commercial bank for deposit withdrawals and any balance sheet gap resulting from its absorbing Bancorex.

From the beginning of 1997 through the end of 2000, the assets of the Romanian banking sector shrunk by about 50\% in real terms. Improved organization of bank supervision did not occur until late in 1999. Romania was both slow to achieve macroeconomic stabilization and slow to recognize bank insolvencies. Although privatizations to foreign investors have begun, the banking system remains fragile.

Russia. The two-tier banking system began in Russia (then Soviet Union) in 1987 with the separation of commercial bank functions from Gosbank ${ }^{8}$ and the creation of sectoral banks by enterprises or former branch ministries. Sberbank, the state savings bank, held most household deposits, which were channeled directly through the state banks to enterprises. New entry into Russian banking was dramatic; a few hundred banks were created in 1988 and 1989 and the number of new banks increased by about 1,000 in 1990 and by another 1,000 shortly thereafter (Aslund, 1996). Most banks were small and poorly capitalized; some of them were merely house banks for enterprises although some later emerged as the largest commercial banks in Russia. In addition, Russia's banking system remained extremely thin throughout the 1990s; the extent of financial intermediation was low even by comparison with other TEs.

Although the Russian banking system was immature, the financial crisis of 1998 exhibited many classical causes. First, asset stripping and excessive risk taking by banks occurred in an environment with little supervision of banks, no uniform accounting standards, and a willingness of the central bank to provide liquidity to the banking system. Second, balance sheet expansion involved both currency and maturity mismatches as the banks bought long-term, high-interest, ruble assets with short-term, and often low-interest dollar-denominated liabilities. Although there was little effort at risk management, the banks remained solvent under Russian accounting standards and prudential regulations. Non-performing loans were reported to be only 19\% of total loans in 1997, which was no higher than in the European TEs and less than in some of the Asian countries that experienced a banking crisis at the same time. However, because of the absence of effective regulation and a program for restructuring, much of the Russian banking system was in serious difficulty even prior to the government debt crisis of 1998 .

The banking crisis only became apparent when the fiscal crisis caused the government to suspend payments on its debt, which resulted in the collapse of the ruble. Bank withdrawals led to an immediate shortage of liquidity. Small banks suffered due to their ties to the large banks and the withdrawal of central bank liquidity after the collapse of the Ruble. The central bank responded by allowing banks to draw on required reserve deposits for payments and by offering stabilization credits to banks. To forestall a bank run, banks were encouraged to shift $50 \%$ of their ruble deposits and $10 \%$ of their foreign 
currency deposits to Sberbank, which was thought to enjoy full implicit deposit insurance because the central bank is its majority shareholder. As the transfer of deposits to Sberbank continued, the quality of its balance sheet deteriorated because it was required to adopt international accounting standards (IMF, 2003)

The full extent of the solvency problem in the banking system was realized in subsequent months, particularly as pressure from international financial institutions led to closer scrutiny of the banks. The Russian authorities agreed to conduct due diligence reviews using Western accounting standards for 18 of the largest banks accounting for about one-half of banking assets outside of state-controlled banks. Legal reforms involving bankruptcy and banking laws to facilitate restructuring and rehabilitation of banks were begun and a commitment was made to strengthen the supervisory capacity of the central bank. However, restrictions on foreign participation in banking remained in place. The number of banks operating in Russia decreased due to closures and consolidations. More importantly, total credit and the real money supply contracted sharply. The credit contraction did not have a larger effect on the economy because of the low level of financial intermediation at the time.

Progress at bank restructuring was slow because the authorities delayed taking actions under the new legislation which only came into effect in mid-1999 and which also encouraged delays. An agency for restructuring problem banks, ARCO, was established but the rules invited procrastination. A bank that fulfilled certain criteria as to size and the nature of their problems had to be referred to ARCO by the central bank. ARCO decides whether to manage or liquidate the problem bank (Chekurova, 2001). The rules are full of contradictions, e.g. ARCO takes on the rights of shareholders at an annual meeting but it may only replace management for one month. Furthermore, although ARCO was responsible for the restructuring program, only the central bank could withdraw a banking license. ARCO had few resources available so it appeared that the government intended to liquidate rather than restructure the large banks. In addition, the interests of individual depositors were disregarded during liquidation as most of the money in the banks was removed shortly before the process began. Caprio and Klingbiel (2003) estimate that the cost of a full bailout of Russian banks was $\$ 15$ billion or between $5 \%$ and $7 \%$ of GDP.

Observers of Russian banking noted immediately the problems with the Russian approach to bank restructuring. First, the limited resources available meant that potentially efficient banks were liquidated, probably by design (Thiesen, 2000). Second, the potential contribution of foreign financial institutions was ignored (Buch and Heinrich, 1999). Third, ARCO itself had little authority to change bank operations and incentives once a restructuring took place.

Although the post-1998 changes were a sharp departure from the wildcat approach to banking that had prevailed, no comprehensive plan for restructuring, no clear and prompt application of prudential rules, and no introduction of private (foreign) capital with the proper incentives were forthcoming (World Bank, 2002). Even if Western prudential standards had been applied to Russian banks prior to 1998, the fiscal 
crisis would have precipitated a banking crisis because the banks were large holders of government debt. Nonetheless, the government's response was inadequate and its mismanagement added to the public perception of the fragility of Russian banks.

The Russian experience provides the best illustration of the importance of having an adequate institutional framework in place. In Russia, the necessary legislation did not exist nor was the commitment to utilize the existing legal structure or the ability to apply existing law forthcoming. In addition, the central bank did not act quickly to begin bank restructuring, even in situations in which it had the authority to do so. Although there are ample reasons to criticize the highly politicized and inconsistent approach to bank restructuring taken by the Russian authorities after the 1998 crisis, the banking system did rebound remarkably in the post-crisis years.

China. China has only recently begun to deal with the problem of nonperforming loans in its four large SOCBs, which account for more than two-thirds of both domestic credits to the non-financial sector and household deposits. Throughout the 1980s and in the first half of the 1990s, bank loans to GDP increased from 50\% to $120 \%$. The Commercial Banking Law, promulgated in 1995, ostensibly made banks responsible for their profits and losses but it also contained language that required banks to conduct lending in accordance with the government's industrial policy. If the latter directive is in conflict with the former, SOCBs cannot be held fully responsible for lending decisions. By 1996, loss-making SOEs were predominant so that the consolidated financial position of the state sector was negative. During this period, the government explicitly sought financial support from the SOCBs in the form of policy loans that accounted for more than one-third of total bank loans in the 1990s (Bonin and Huang, 2001).

The Chinese government began to address the bad loan problem in 1994 by creating three banks to take over policy lending. By 2000, the policy banks accounted for over $12 \%$ of bank loans in China. In 1999, the Chinese government established four asset management companies (AMCs), one associated with each of the four large SOCBs, to deal with non-performing loans amounting initially to about $19 \%$ of the total loans on the books of SOCBs. By attaching each AMC to a large SOCB, the Chinese government created an incentive problem. Even though a sunset provision has been imposed on the AMCs, a SOCB is likely to view its AMC as a bin into which bad loans can be discarded continuously. Simultaneously, the government has been pursuing a program of restructuring and downsizing SOEs. Hence, the clients of the SOCBs are becoming stronger financially. At the same time, the private sector is growing rapidly, providing banks with healthy potential clients. Current Western estimates indicate that the totality of bad loans in banks and AMCs constitute about $40 \%$ of GDP. To what extent China can grow out of this bad loan problem and to what extent the large SOCBs will require considerable recapitalization is an ongoing concern for the government.

In many TEs, privatization of SOCBs to majority foreign owners established an arms-length regulatory relationship between the government and the banks and provided credibility to the no-bailout commitment. The four large Chinese banks will not be privatized in this way in the foreseeable future. In addition, Chinese banks are protected 
from outside competition because the capital account remains closed and operations of foreign financial firms are limited, despite China’s recent entry into the WTO. Hence, considerable institution building and gradual divesting of government stakes in the SOCBs by sales in the stock market must be combined to impose the necessary financial discipline on China's four large banks. The final cost of the eventual resolution of bank insolvencies in China is likely to be toward the upper range for the TEs and may be as large as $40 \%$ of GDP.

\section{Conclusion}

The experiences with bank resolution in the transition countries are related to peculiar aspects of the transition and to idiosyncrasies of a particular country's banking sector; nonetheless several overall lessons can be drawn. First, insolvency will continue to plague the banking system so long as the incentive structure that encourages banks to support weak SOEs is not changed. By its nature, banking is a relational business and bad relationships are hard to break; removing inherited bad loans from banks is less important than freeing banks from inherited bad clients. Czech voucher privatization strengthened the ties between weak enterprises and their banks; in contrast, although the Hungarian program involved multiple recapitalizations of banks, it addressed the issue of bad relationships. As a result, the Czech Republic took over a decade to deal with soft lending whereas Hungary moved relatively quickly to change the incentive structure in banks by selling banks to foreign owners. Thus, the final cost of bank resolution in the Czech Republic was more than double that in Hungary.

Second, the method chosen to deal with bad loan problems can reinforce the bad relationships that are responsible for insolvency problems. Bank involvement with workouts is likely to perpetuate the relationship to the bad customer, as the Polish experience indicates. However, establishing a hospital bank or an asset management company to workout the bad loans creates a moral hazard dilemma because of the expectation of further government- financed purchases of bad loans. The Czech Republic fell victim to this trap and China appears to be doing the same because the asset management companies are associated with a particular bank. Therefore, neither a centralized hospital bank solution nor a decentralized program leaving responsibility for bad loan workout with the banks is a panacea.

Third, repeated recapitalizations strengthened direct ties between the government and banks making a credible commitment to arms-length regulation difficult. Hungary used the sale of the banks to foreign investors to remove the government from bank-client relationship. The establishment of a currency board in Bulgaria provided a credible legal constraint on bailout activity that was strengthened by subsequent rapid sales of the banks to foreigners. Continued state-ownership of banks invites ongoing government intervention and impairs the ability of regulators to act independently. The conflict of interest faced by the Russian central bank as both regulator and owner of Sberbank and government ownership of the four large Chinese banks are prime examples. Continued state-ownership of the savings banks in Romania and Poland, an agricultural bank in Poland, and the largest commercial bank in Romania also permit these governments to pursue industrial policy through banks to the detriment of effective regulation. 
Fourth, institutions matter but formal legislation is less important than the ability to implement vigorously equitable and transparent supervision. The absence of prudential institutions or the lack of skills among regulators impeded crisis resolution in the Bulgaria, Romania, and Russia. Finally, resolving bank crisis in transition countries is only weakly related to macroeconomic performance. In the Czech Republic, Romania, Russia, and Poland, economic growth resumed before bank insolvencies were fully resolved. In addition, China has an exemplary record of high growth and low inflation. On the other hand, in recent years, Hungary has grown faster than the Czech Republic and Poland while Bulgaria has grown slightly faster than Romania. Hence, experiences in the transition countries lend weak support to the thesis that the failure to address financial fragility is a deterrent to sustainable economic growth. 


\section{References}

István Ábel, 2002, "Real Dangers in Banking Crises: Examples of Failed Hungarian Banks," in Banking and Financial Stability in Central Europe, D. Green and K. Petrick (eds.), Northampton, MA, Edward Elgar Publishing.

Anders Aslund, 1996, “Russian Banking: Crisis or Rent-Seeking?” Post-Soviet Geography and Economics, Vol. 37, No. 8, pp. 495-502.

John Bonin, 2004, "Banking in the Balkans: the structure of banking sectors in Southeast Europe,” Economic Systems, Vol. 28, pp.141-53.

John Bonin and Yiping Huang, 2001, "Dealing with the bad loans of the Chinese Banks," Journal of Asian Economics, Vol. 12, pp. 197-214.

John Bonin and Bozena Leven, 2001, “Can State-Owned Banks Promote Enterprise Restructuring?: Evidence From One Polish Bank’s Experience,”, Post-Communist Economies, Vol. 13, No. 4, pp. 431-44.

John Bonin and Paul Wachtel, 2003, "Financial Sector Development in Transition Economies: Lessons from the first Decade,' Financial Markets, Institutions and Instruments, Vol. 12, pp. 1-66.

Claudia Buch and Ralph Heinrich, 1999, "Handling Banking Crises: The Case of Russia,” Economic Systems, Vol. 23, December, pp. 349-80.

Gerard Caprio and Daniela Klingbiel, 1999, "Episodes of Systemic and Borderline Financial Crisis,” World Bank, October and dataset, January 2003. http://econ.worldbank.org/view.php?type=18\&id=23456

Marina Chekurova, 2001, "Restructuring the Russian Banking System,” in Financial Transition in Europe and Central Asia, Lajos Bokros, Alexander Fleming and Cari Votava (eds.), Washington, D.C., World Bank.

Charles Enoch, Anne-Marie Gulde and Daniel Hardy, 2002, "Banking Crises and Bank Resolution: Experiences in Some Transition Economies,” IMF Working Paper, 02/56.

Roman Matousek and Anita Taci, 2002, "Banking Regulation and Supervision in Associated Countries: A Case Study of the Czech Republic,” in Banking and Financial Stability in Central Europe, D. Green and K. Petrick (eds.), Northampton, MA, Edward Elgar Publishing.

Helena Tang, Edda Zoli and Irina Klytchnikova, 2000, "Banking Crises in Transition Countries: Fiscal Costs and related Issues,” World Bank Working Paper 2484, November. 
World Bank, 2002, Building Trust: Developing the Russian Financial Sector.

Edda Zoli, 2001, "Cost and Effectiveness of Banking Sector Restructuring in Transition Economies,” IMF Working Paper 01/157, October 2001. 


\section{Appendix Tables}

Table 1: Real GDP Growth Rates

$\begin{array}{lccccccc} & \text { Bulgaria } & \text { Czech Republic } & \text { Hungary } & \text { Poland } & \text { Romania } & \text { Russia } & \text { China } \\ \mathbf{1 9 9 0} & \text { n.a. } & \text { n.a. } & -3.5 & -11.6 & -5.6 & \text { n.a. } & 3.8 \\ 1991 & \text { n.a. } & -11.5 & -11.9 & -7.0 & -12.9 & -5.0 & 9.2 \\ \mathbf{1 9 9 2} & \text { n.a. } & -3.3 & -3.1 & 2.6 & -8.8 & -14.5 & 14.2 \\ \mathbf{1 9 9 3} & -1.5 & 0.6 & -0.6 & 3.8 & 1.5 & -8.7 & 13.5 \\ 1994 & 1.8 & 3.6 & 2.9 & 5.2 & 3.9 & -12.7 & 12.6 \\ \mathbf{1 9 9 5} & 2.9 & 5.9 & 1.5 & 7.0 & 7.1 & -4.1 & 10.5 \\ \mathbf{1 9 9 6} & -9.4 & 4.3 & 1.3 & 6.0 & 3.9 & -3.6 & 9.6 \\ \mathbf{1 9 9 7} & -5.6 & -0.8 & 4.6 & 6.8 & -6.1 & 1.4 & 8.8 \\ \mathbf{1 9 9 8} & 4.0 & -1.0 & 4.9 & 4.8 & -4.8 & -5.3 & 7.8 \\ \mathbf{1 9 9 9} & 2.3 & 0.5 & 4.2 & 4.1 & -1.2 & 6.3 & 7.1 \\ \mathbf{2 0 0 0} & 5.4 & 3.3 & 5.2 & 4.0 & 2.1 & 10.0 & 8.0 \\ \mathbf{2 0 0 1} & 4.1 & 3.1 & 3.8 & 1.0 & 5.7 & 5.1 & 7.5 \\ \mathbf{2 0 0 2} & 4.9 & 2.0 & 3.5 & 1.4 & 5.0 & 4.7 & 8.0 \\ \mathbf{2 0 0 3} & 4.3 & 2.9 & 2.9 & 3.8 & 4.9 & 7.3 & 9.3\end{array}$

Table 2: Inflation Rates

Annual average \% change in Consumer Prices

$\begin{array}{cccccccc} & \text { Bulgaria } & \text { Czech Republic } & \text { Hungary } & \text { Poland } & \text { Romania } & \text { Russia } & \text { China } \\ \mathbf{1 9 9 0} & \text { n.a. } & \text { n.a. } & 28.9 & 600.0 & \text { n.a. } & \text { n.a. } & 18.8 \\ \mathbf{1 9 9 1} & 419.2 & \text { n.a. } & 34.2 & 76.6 & 133.3 & \text { n.a. } & 3.6 \\ \mathbf{1 9 9 2} & 91.3 & 11.1 & 23.0 & 45.3 & 225.0 & \text { n.a. } & 6.3 \\ \mathbf{1 9 9 3} & 72.8 & 20.8 & 22.4 & 36.9 & 250.5 & 890.0 & 14.6 \\ \mathbf{1 9 9 4} & 96.0 & 9.9 & 18.8 & 33.2 & 137.9 & 307.6 & 24.2 \\ \mathbf{1 9 9 5} & 62.1 & 9.2 & 28.3 & 28.0 & 32.1 & 197.4 & 17.1 \\ \mathbf{1 9 9 6} & 121.6 & 8.8 & 23.4 & 19.8 & 39.0 & 47.7 & 8.3 \\ \mathbf{1 9 9 7} & 1058.4 & 8.4 & 18.3 & 15.1 & 154.7 & 14.8 & 2.8 \\ \mathbf{1 9 9 8} & 18.7 & 10.6 & 14.2 & 11.7 & 59.2 & 27.7 & -0.8 \\ \mathbf{1 9 9 9} & 2.6 & 2.1 & 10.0 & 7.3 & 45.8 & 85.7 & -1.5 \\ \mathbf{2 0 0 0} & 10.3 & 3.9 & 9.8 & 10.1 & 45.6 & 20.8 & 0.4 \\ \mathbf{2 0 0 1} & 7.4 & 4.7 & 9.2 & 5.5 & 34.5 & 21.5 & 0.7 \\ \mathbf{2 0 0 2} & 5.8 & 1.8 & 5.3 & 1.9 & 22.5 & 15.8 & -0.8 \\ \mathbf{2 0 0 3} & 2.3 & 0.1 & 4.7 & 0.7 & 15.3 & 13.7 & 1.2\end{array}$


Table 3: M2/GDP

$\begin{array}{cccccccc} & \text { Bulgaria } & \text { China } & \text { Czech Republic } & \text { Hungary } & \text { Poland } & \text { Romania } & \text { Russia } \\ \mathbf{1 9 9 0} & \text { n.a. } & 0.18 & \text { n.a. } & \text { n.a. } & \text { n.a. } & \text { n.a. } & \text { n.a. } \\ \mathbf{1 9 9 1} & 0.10 & 0.19 & \text { n.a. } & \text { n.a. } & \text { n.a. } & \text { n.a. } & \text { n.a. } \\ \mathbf{1 9 9 2} & 0.14 & 0.20 & \text { n.a. } & \text { n.a. } & \text { n.a. } & \text { n.a. } & \text { n.a. } \\ \mathbf{1 9 9 3} & 0.16 & 0.25 & 0.22 & 0.23 & 0.11 & 0.03 & 0.04 \\ 1994 & 0.14 & 0.20 & 0.26 & 0.23 & 0.13 & 0.05 & 0.04 \\ 1995 & 0.17 & 0.23 & 0.33 & 0.21 & 0.16 & 0.06 & 0.07 \\ \mathbf{1 9 9 6} & 0.06 & 0.26 & 0.32 & 0.21 & 0.16 & 0.06 & 0.08 \\ \mathbf{1 9 9 7} & 0.08 & 0.29 & 0.26 & 0.19 & 0.16 & 0.06 & 0.09 \\ \mathbf{1 9 9 8} & 0.09 & 0.31 & 0.31 & 0.19 & 0.19 & 0.07 & 0.04 \\ \mathbf{1 9 9 9} & 0.08 & 0.32 & 0.26 & 0.18 & 0.18 & 0.06 & 0.04 \\ \mathbf{2 0 0 0} & 0.09 & 0.33 & 0.27 & 0.17 & 0.19 & 0.06 & 0.06 \\ \mathbf{2 0 0 1} & 0.10 & 0.34 & 0.30 & 0.19 & 0.22 & 0.06 & 0.07 \\ \mathbf{2 0 0 2} & 0.13 & 0.37 & 0.37 & 0.26 & 0.21 & 0.08 & 0.08 \\ \mathbf{2 0 0 3} & 0.18 & 0.40 & 0.44 & 0.30 & 0.22 & 0.09 & 0.11\end{array}$

Table 4: Domestic credit provided by banking sector (\% of GDP)

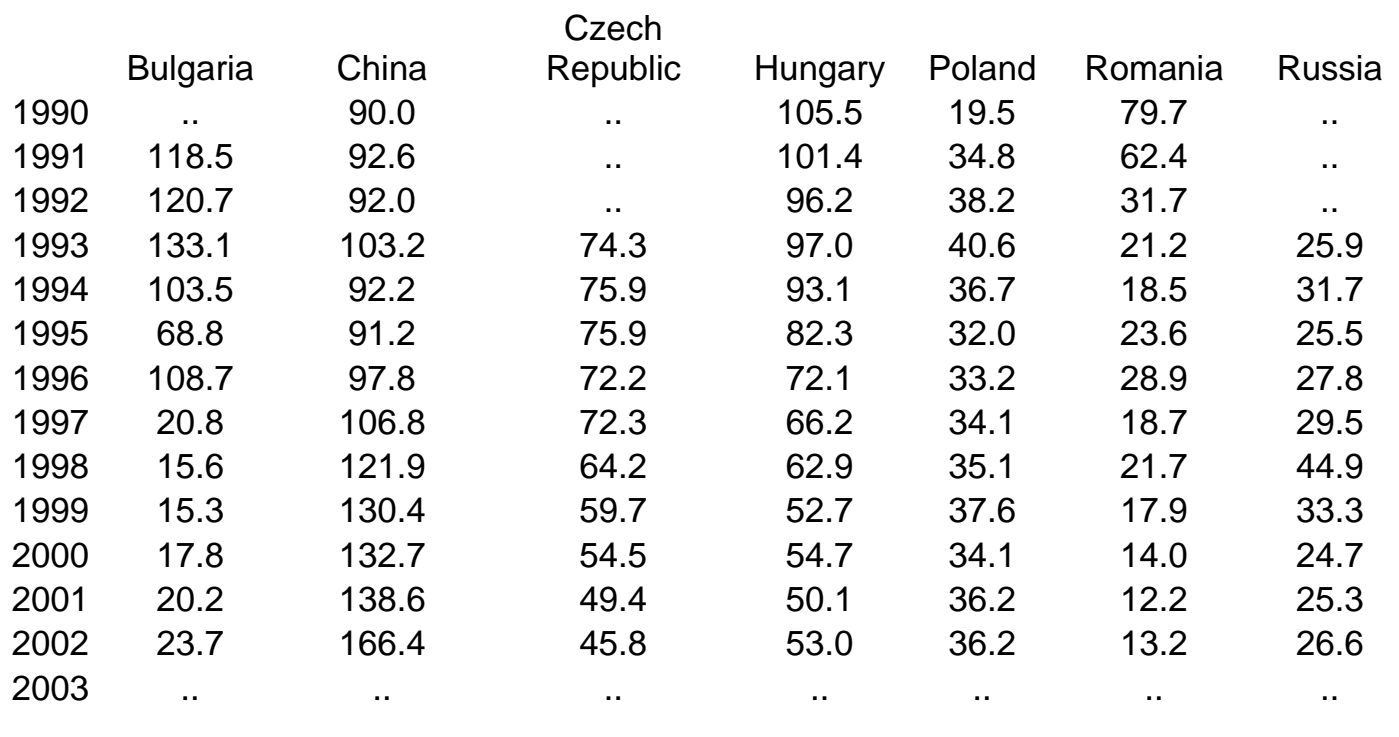

Sources:

Tables 1-3: Economist Intelligence Unit (EIU)

Table 4: World Bank, World Development Indicators (WDI) 
${ }^{1}$ Although Russia experiences an episode of negative real growth and high inflation in 1998, the main cause of this retrenchment is the financial crisis'

${ }^{2}$ All the transition countries have much less developed financial systems than other countries at the same level of economic development (Fries and Taci, 2001).

${ }^{3}$ This was the situation in many of the least developed TEs, which is one reason that we do not examine bank restructuring in countries like Armenia or Kyrgyzstan

${ }^{4}$ Zoli's estimate appears to ignore the continued and ongoing fiscal support for the stateowned savings bank and agricultural bank.

${ }^{5}$ Abel (2002) provide more information on Hungarian banking.

${ }^{6}$ All the figures here are present values in 1998 as a percent of 1998 GDP, as calculated by Tang, et. al. (2000).

${ }^{7}$ Of course, a country must have a significant banking sector to incur large restructuring costs. If fiscal transfers financed by monetary expansion are used to support loss-making enterprises, as in Ukraine, explicit bank restructuring costs may not be incurred. However, the economy still suffers efficiency losses and costs from macroeconomic instability.

${ }^{8}$ With the exception of Sberbank, the former state-owned banks went through a metamorphosis during privatization as branches became independent entities and then regrouped into larger banks. 